training. This will be studied by the Standing Committee of the AUTP with a view to making recommendations to the Education Committee and the Examinations Sub-Committee.)

\section{Feedback}

The present arrangements for providing information about a candidate's performance in the Examination are that with the candidate's written consent information is sent to his tutor (or consultant chief). Information is not given directly to candidates' nor is it given to tutors without the candidates permission. Some trainees had been unaware that some information about performance could be fed back to candidates and tutors. It was pointed out that information could now be given on the results in three sub-sections of the Multiple Choice in the Preliminary Test (1. Neurobiology and Genetics; 2. Psychology, Statistics and Child Development; 3. General and Dynamic Psychopathology), but it was not possible to do this for the MCQ in the Membership Examination itself, since all sub-sections would be very small. Other feedback depended on the reports written by examiners on essays, clinicals and vivas. There was discussion of how to improve this to provide better feedback to candidates' tutors, and this will be one of the topics for discussion by examiners later in 1980 .

THOMAS BeWLEY Dean

\title{
FORENSIC PSYCHIATRY SECTION
}

\author{
Honorary Secretary's Report
}

During the year contributions have been made to the College's evidence to the Royal Commission on Criminal Procedure, and the Committee of Inquiry into the Prison Services. A Working Party examined the role of the visiting psychotherapist in penal establishments and made recommendations concerning the Home Office panel of consultant psychiatrists. Professor Bluglass chaired the Special Committee of Council considering the White Paper on the Menta Health Act, and the College continues its discussion in this area with HM Government.

At the request of the Section, a Special Committee of Council was set up on Regional Secure Units, and is soon to report. Members of the Executive Committee continue to serve on the Secretary of State's Advisory Group on Regional Secure Units.

The Forensic Psychiatry Advisory Sub-Committee of the
JCHPT has completed its preliminary assessment of senior registrar training posts in the specialty.

In September 1979 a symposium was held at Pidgate College on the subject of Regional Secure Units, and in March of this year the Section held a conference on Mental Disorder and Crime.

The Appeal to commemorate the late Dr Peter Scott has resulted in the establishment of a trust fund, and the inaugural Peter Scott Lecture was given by Sir Leon Radzinowicz at the Spring Quarterly Meeting 1980.

We record with pleasure the election of Professor Gibbens to an Honorary Fellowship of the College, and the appointment of our Chairman, Dr Bluglass, to be Professor of Forensic Psychiatry at the University of Birmingham.

P. BOWDEN

Honorary Secretary

\section{ELECTION OF FELLOWS}

The following Members have been elected to the Fellowship:

Shirley A. Abell, A. B. Ahmed, F. T. Antun, A. Anumonye, G. H. B. Baker, P. A. Barker, S. Benjamin, A. W. Black, I. F. Brockington, J. M. Carliste, Enda Casement, E. S. Chesser, R. H. Culpan, L. N. Daly, G. Davies, T. G. Davies, S. A. Dissanayake, M. F. Dixon, Marjory Foyle, P. L. Gallwey, E. B. Gordon, J. Gotea-Loweg, J. M. G. Grigor, J.C. Gunn, M. T. Haslam, C. F. Herridge, R. N. Herrington, R. C. Hicks, J. P. Horder, B. D. Hore, Edna Irwin, B. James, H. V. R. Jones, N. Kaye, Arthur Kerr, G.
Kerr, K. M. Koller, N. I. Lavin, J. S. Lyon. A. A. McKechnie, G. P. Maguire, Helen Mair, Sheila Mann, A. Morrison, Isabel Moyes, A. A. Nadim, H. S. Obeid, E. G. Oram, T. P. Powell, J. Price, A. L. Proctor, P. H. Rack, S. Rajah, A. H. Reid, E. B. Ritson, M. A. H. Russell, Elsie Rue, A. Ryle, S. M. Saleh, M. R. Salkind, V. Satkunanayagam, J. P. Scrivener, S. M. Smith, R. P. Swinson, G. F. Spaul, Uma Sreenivasan, Sabina Strich, M. J. Tarsh, C. J. H. Thesiger, D. O. Topp, R. J. Wawman, C. A. H. Watts, A. D. Weatherhead, M. G.T. Webb, E. Wilkes, N. Win, Lorna Wing, Imre Zador. 